\title{
Influence of Leadership, Loyalty, and Followership on Team Performance of P.T. Gaharu Galangan International
}

\author{
Endang Tri Pujiastuti ${ }^{1}$, Hasri Nirmala Budiarti ${ }^{2}$, Karina A. Sulaeman ${ }^{3}$, Danny Faturachman ${ }^{4}$, Rini Setiawati ${ }^{5}$ \\ (Received: 01 August 2019 / Revised: 18 June 2020 / Accepted: 25 June 2020)

\begin{abstract}
This research identifies influence of variables of leadership, followership and loyalty on team performance. This research is quantitative research on path analysis by using SPSS program. The result is loyalty and followers don't have direct positive effect on team performance, but through leadership variable as intervening variable. Leadership variable has direct positive effect on team performance and loyalty, and followership variable has direct positive effect on leadership variable.
\end{abstract}

Keywords — followership, leadership, loyalty, path analysis.

\section{INTRODUCTION}

M any factors are considered influencing team or group performance, leadership is absolutely required for the collaboration of a working group to achieve organization goal. A leader is expected to play as role model to move his subordinates for successful goal achievement, but this success totally depends on individuals inside the organization. Working group consists of a group of people with various skills, talents, experiences and backgrounds who works together to achieve common goal. Even though there is difference among them, this common goal is a connection to unite all of them into one working team

According to Amstrong and Baron [1], organization performance depends on several factors. First is personal factor that covers individual skills, competency, motivation and comittment. Second is ledership factor that covers motivation, guidance and support given by the leader. Third is team factor that covers support quality given by the colleagues. Fourth is system factor that covers working system dan facilities provided by organization. Fifth is contextual or situational that covers pressure and situation change internally and externally. So it is said that organization success depends not only on the leader but also on supports by the skillful followers. Leader is like a brain that is so thristy to coordinate movement and direction performed by body organs to arrive at a certain point but if the body organs aren't perfect, the ability and speed of that person to arrive at the

Endang Tri Pujiastuti is with Departement of Management, Darma Persada University, Jakarta, 13450, Indonesia,

endangtutietp_tuti@yahoo.com

Hasri Nirmala Budiarti is with Department of Accounting, Darma Persada University, Jakarta, 13450, Indonesia,

hasri.fe.unsada@gmail.com

Karina A. Sulaeman is with Department of English Language and Culture, Darma Persada University, Jakarta, 13450, Indonesia,

karina adinda@yahoo.co.id

Danny Faturachman is with Department of Marine Engineering, Darma Persada University, Jakarta, 13450, Indonesia, fdanny30@yahoo.com

Rini Setiawati is with Department of Management, Binus University, Jakarta, 11480, rinikimi@yahoo.com destination will be lessening. To study the role of followers on organization sucess

Kelley [2] adduces followership concept, that is behavior associated with decent follower. Followership concept is a concept completing leadership concept discussion. Kelley explains that there are people dare to pursue their dream altogether and they exist in the society without targeting to be leader, seeking status and fame, or other wordly attributes. Recently followership is a research theme that is getting more popular to conduct along with increasing awareness of academia that organization success depends not only on qualified leadership but also on qualifed followership.

A follower is a person involved directly to meet target of company, taking part actively in problem-solving of emerging problem in meeting target also actively providing feedback and creative innovation to lead into target accomplishment. A follower is not a 'lamb' that doesn't have capacity to give instructions. Kelly also says that a great leader at the beginning was a great follower that eventually is trusted to be a leader. An employee in bureaucracy or institution has rights and obligations to do which both are interrelated links. Rights come after the obligations are executed, while obligations are mandatory to do. Therefore an employee has the right to get income based on the existing regulation, whereas his obligation is to do the job responsibly according to his role. Responsibility in this case is related to employee's obligation to do the job seriously and accordingly as given by someone/institution. "Responsibility in work is to do the job completely, without procrastination so that the work will increase, be more qualified and be held accountable officially and legally. That opinion emphasizes that responsibility shows level of work accomplishment and quality of work result that leads to the creation of efficiency and affectivity in completing the work. Efforts to increase work productivity in achieving goal needs high responsibility in all personnel in the organization. By way of decent responsibility, job is expectedly done fast with better result as productivity is not only depending on moral factor, but there are many other factors, yet moral is still taking major role mentally.

P.T. Gaharu Galangan Internasional (P.T. GGI) is a company running in repair service and building of ships. 
Established in 2011 based on the Deed of Company Establishment no. 18 dated February 9, 2011. Vision of Company is to be a company taking active role in supporting maritime industry development professionally in national and regional markets. Mission of the company is to get benefits and growing business continuously with the support of market, technology, and professional and experienced management team that can contribute to growing national economy, give welfare to employees and community as well as provide benefits to shareholders.

Main office is in Jakarta while branch office and shipyard are in Banjarmasin. Entire operational activities are in Banjarmasin and shipyard is led by an Operational Director who supervises Department Heads located in Banjarmasin. The problem is since its inception, in 7 years the company has not met its targeted profit based on target of the company. Initially Management of P.T. GGI thought the main cause was the failure of the leader in running this business. That is why management changed the leaders from Director to Manager Level but still this hasn't shown any significant progress. Based on that background, researchers were interested to identify role of followers or in this case is employees of P.T. GGI, to the question if majority of employees have already had followership character or not, and the relationship between upper and lower employees, also responsibility of each superior and underling in working together as a team

\section{A. Leadership}

Leadership is a field of study that has long attracted many people. That term portrays strong and dynamic individual image that leads a group of people and determines direction of that group. Leadership is a desired commodity that has high value. Many people keep asking themselves or other people concerning elements that create a leader. As individual, they seek more information regarding how to make someone a good leader. Many people believe leadership is the way to increase their personal, social and professional life.

Company seeks someone with leadership skill because this kind of person will bring special asset to the company and finally will increase profit [3]. Leadership is deemed a requirement to successful organization. Currently, considering the fast growing and development of communication technology along with the rise of international business by way of globalization, leadership issue is becoming vital factor compared to previous eras [4].

Analysis on leadership study from academia shows there are various different theoretical approaches to explain leadership process complexity. Topic on leadership is always interesting to study. Maxwell states that everything depends on leadership. If we want to make positive change in the world, learning to lead better is the key to make it [5]. Leadership term is taken from generally used vocabulary and put into technical vocabulary of certain field without being defined appropriately. Consequently, this word has irrelevant connotation that creates ambiguous meaning. Gary Yukl [6] quotes observation conducted by [7] that it is still relevant even though it was formulated years ago.
Seemingly, leadership concept is always confusing us or it appears in other form to again seduce us with uncertainty and complexity. So we have to continuously generate terms to resolve that and yet that concept still cannot be exactly defined [6].

There are many different definitions of leadership, as many as number of people tries to define this word. Despite the fact that each of us knows intuitively what we mean by leadership, but still leadership word has different meaning to different person. Academician and practitioners have attempted to formulate leadership definition for more than a century without universal consensus. Researcher usually comes up with the definition based on his individual perspective and pattern aspects mostly interest his attention [3]. Most definition reflects the assumption that leadership links to deliberate process of someone to other person to guide, develop structure, and facilitate activities and relationship in the group or organization.

These many leadership definitions appear to have little similarities. The definitions differ in various aspects regarding who can instill the influence, target of influence, attitude to embed the influence, and result of the influence itself. These differences are not only from scientific point of views. These differences show deep disagreement concerning leader identification and leadership process. Researchers with different leadership concept prefer different phenomenon to study and conclude the result differently too. Researchers with narrow leadership definition almost impossible find unrelated or inconsistent matters with their early assumption on effective leadership [6]. Even though many people have deep understanding on leadership meaning, but efforts to define one term is proven challenging both for academician and practitioners. Leadership has been academia introspection topic more than a century ago, and this definition has been transforming continuously during that period. These definitions have been influenced by many factors from word and political issues on discipline perspective where the topic is studied.

Many questions on leadership have been speculation subject, but scientific study has been started after $20^{\text {th }}$ century. Research focus of researchers has been more toward leadership effectiveness. Social scientists have been trying to identify characteristics, skills, behaviors, power sources or situational aspects to determine how good a certain leader to influence the followers and achieve the goals. Besides, researchers are having growing interest on understanding leadership as common process involving various people in a team or certain organization and the reason why this process is effective or not. Another important question is why several people appear as leader and determining factor of leader's action, but the most drawn attention is leadership affectivity.

\section{B. Loyalty of Employees}

Robbin and Coulter opine that loyalty is willingness to protect and save someone physically and emotionally [8]. This is supported by loyalty definition formulated by Siswanto [9] loyalty is determination and willingness to obey, do and practice something to be adhered to with full consciousness and responsibility. That determination and willingness has to be proven in the attitude and behavior 
of the related employee in daily activity and in his doing his task and work given to him. This definition is also rendered by Saydam [10]. In accordance with Siswanto's definition, Yusuf [11] suggests that loyalty is arisen attitude as the consequence of desire to be loyal and dedicating to the work, group, supervisor and the working place that makes willingness of someone to sacrifice to satisfy other party or society. This has been conveyed by stating that: first, loyalty to the company as attitude that is how far an employee identifies his desired working area by working and attempting the best; second, loyal to the company as attitude, that is process where an employee takes certain decision not to exit the company if he doesn't make extreme mistake. Based on above elaboration, it can be concluded that loyalty of employee is willingness of employee to do company's task responsibly and consciously in order to succeed company's goal maximally.

\section{Followership}

Several definitions of follower are as follows: an individual who is willing to follow a leader [12], individual who not only understand and takes participation in vision and goal of leader but also with vision and mission of the company. Kelley as the first researcher who introduces followership concept as a capacity and desire to perform certain behavior with the aim to participate in achieving common goal [2].

Based on above opinions followers are people who know what to do without waiting for direction and also able to act independently and enthusiastically to achieve goal decided by the organization. Currently followership is a research theme that is getting popular to study along with the increasing awareness of academician on the idea that success of an organization is not only depending on qualified leader (leadership) but also on qualified follower (followership). W. Bennis said that effective leadership cannot happen without involvement, initiative and cooperation of the followers [7].

Leader in organization can be follower too due to getting command from higher level of leader. So all leaders are followers but not all followers are leaders. According to Kelly followership concept is more common concept and can be found much more in daily life compared to leadership concept, this is because a leader once was an employee. There are 2 dimensions of followership, they are a) Active Engagement ( $A E$ ), dimension that covers behavior of follower where they willingly follow and do activity and program of the company. Individual with this dimension will demonstrate attitude and behavior in line with policy of the organization even though those followers won't get reward from the organization directly, b) Independent Critical Thinking, this dimension explains how a follower isn't "a lamb" who can only follow direction from the shepherd without having critical thinking ability and doesn't have ability to create important innovative breakthrough. On the other hand, this dimension is the most important dimension of the follower where it guards the policy direction adopted by the organization to run through correct corridor and actively takes role seeking way-out from problem and new breakthrough innovatively and efficiently.

According to Kelly in Bennis [7] followership type based on that dimension can be seen in table 1 below:

TABLE 1. TYPE OF FOLLOWERSHIP

\begin{tabular}{lll}
\hline \multicolumn{1}{c}{ Type } & AE & ICT \\
\hline The Ship Followers (Passive Follower) & Low & Low \\
The yes - people followers (Obedient Follower) & High & Low \\
The Alienated Followers (Passively critical Follower) & Low & High \\
The Pragmatic Followers (Opportunistic Follower) & Medium & Medium \\
The Star Followers (Role model Follower) & High & High \\
\hline
\end{tabular}

Effective followership behaviors according to Howel \& Mendezz in Bennis [13] are (1) able to show competency and master needed skills to perform well in working environment and useful to the organization, (2) can build collaboration relationship, that is supporting each other and cooperate mutually with office colleagues and the leader, (3) can protect and support the leader in front of people, (4) can influence the leader to be more confident and unemotional to avoid mistakes, (5) can show appropriate behavior for organization in verbal, appearance and ethics, (6) dan show commitment and care to organization performance along with building friendly working environment. There are three factors to influence individual followership:

1) Character (Trait), several characters related to followership are :

a) Intelligence, intelliegence allows individual to act right without direction from superior at all . b) Independent thinking, this character allows individual to be more initiative in thinking and able to anticipate future problem.

c) Self-reliance, this character allows individual to act independently.

d) Dependability, individual with this character will be more trusted by the superior in decisionmaking process.

2) Relationship between superior and underling, binding relationship between both parties allows followers to learn and refer the superior. This can support company's goal achievement effectively. Organizational climate reflects existing synergy among individuals in the organization.

3) In organizational climate there is reciprocal relationship between individual and superior or organization. If best-performing individual gets appreciation from superior, the impact received by individual is satisfaction feeling and work 
convenience that the final result will affect the increasing performance of the individual.

AB Soesanto [14] in his book reminds that a good leader is also a good follower. Without support from follower, very unlikely leader will succeed. This concept is known as followership quantum. Leadership quantum and followership quantum will create one solid unity. One cannot be a good leader wihthout previously being a good follower. Followership concept Figure is as belows:

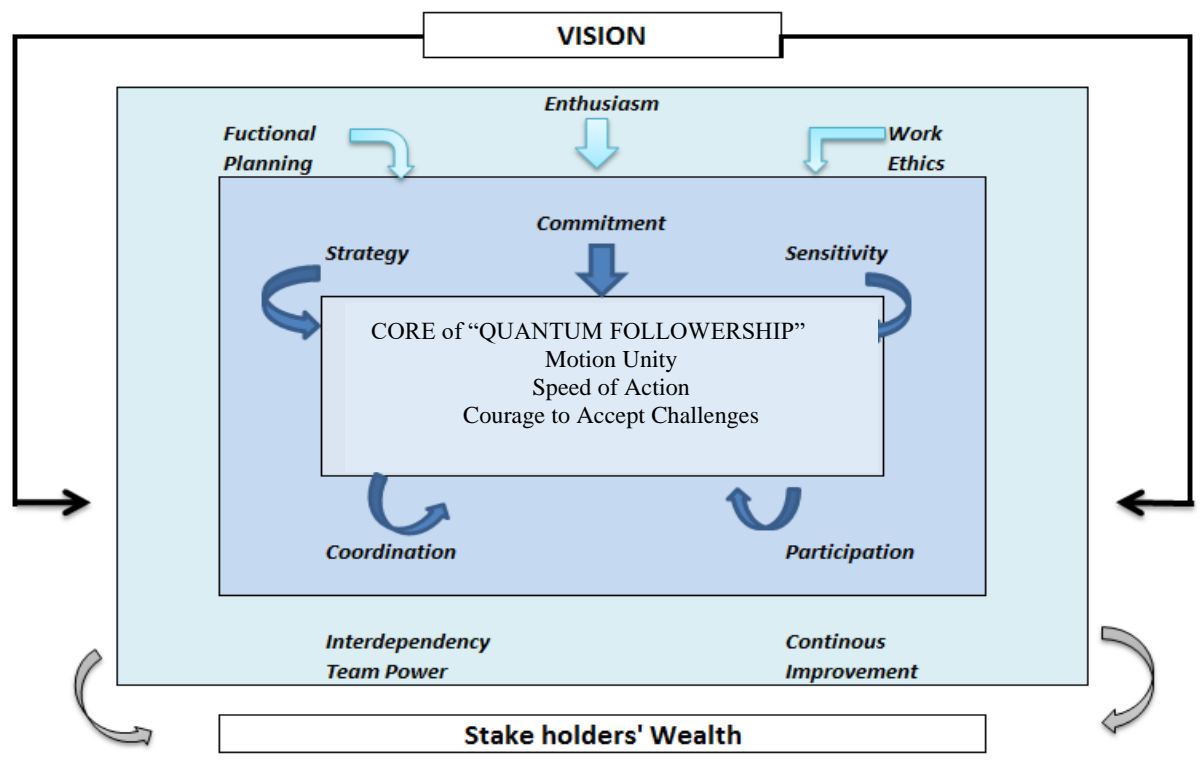

Figure. 1. Followership concept.

This concept has three core matters; they are unified movement, action speed and challenge-accepting courage. This concept is supported by five components they are strategy, commitment, sensitivity, coordination and participation. Furthermore, five more applicable components to execute will be derived from both core and supporting components. Final goal is for stakeholder's wealth. Speed of organization movement will be manifested in coordination between leader and subordinates while participation is other side of action. Leader acts - to give orders and simultaneously participate in entire organization activity. LeadershipFollowership is united in one principle so-called ELITE concept. This elite concept is translated into work ethics, mid-range planning (functional planning), Continuous improvement, interdependecy team power and enthusiasm of members.

\section{Team Performance}

Basically performance is task accomplishment by individual and collective in the group. Performance is real behavior demonstrated by every person as work achievement produced by employee in accordance with his role in the company, meanwhile Husna \& Hussain [26] said that performance is same with work achievement as a sign of organization success and people inside the organization. Performance Management Model in organization entails four interdependent factors, they are (1) individual attribute, (2) organization strategy, (3) situatioal obstacle and (4) desired goal. This shows that performance value has to be considered organizational strategic activity to propel performance, development, rights protection (compensation) and measurement to obligations and responsibility of employee in doing the tasks [15].

\section{E. Research Hypotheses}

Based on theory study and intended frame of mind, it can be formulated that hypotheses of this research are in the elaboration and statements below:

1) There is direct positive influence of Loyalty $\left(X_{1}\right)$ to Team Performance (Y).

2) There is direct positive influence of Followership $\left(X_{2}\right)$ to Team Performance (Y).

3) There is direct positive influence of Leadership $\left(\mathrm{X}_{3}\right)$ to Team Performance (Y).

4) There is direct positive influence of Loyalty $\left(X_{1}\right)$ to Leadership $\left(\mathrm{X}_{3}\right)$.

5) There is direct positive influence of Followership $\left(\mathrm{X}_{2}\right)$ to Leadership $\left(\mathrm{X}_{3}\right)$.

6) There is direct positive influence of Loyalty (X1) to Followership (X2).

\section{METHOD}

\section{A. Research Design}

This research had been conducted in P.T. Gaharu Galangan Internasional (P.T. GGI) for 6 months starting from March 2018 until August 2018. This research is descriptive research because the goal is to describe the condition as it is. In order to do that this research implements Survey Method with Associative Model Quantitative and Path Analysis Model. The variables are endogenous variable that is Team Work (Y) and exogenous variable that is Loyalty (X1) and Followership (X2), and intervening variable Leadership (X3). 


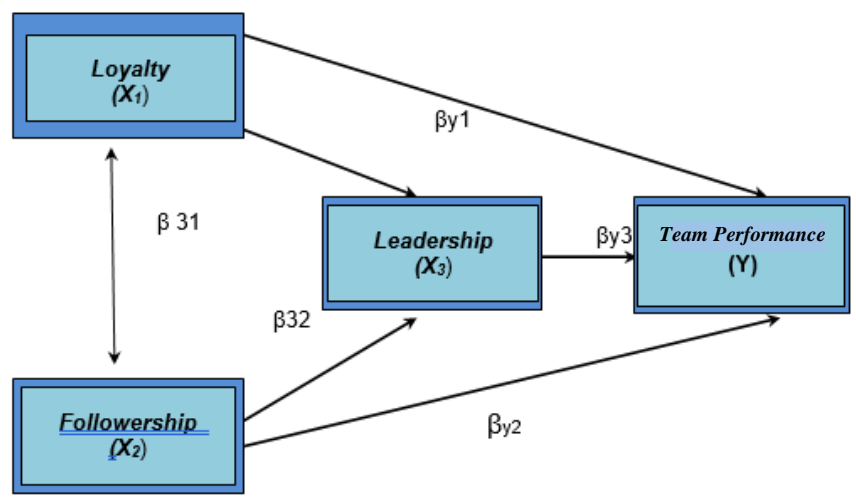

Figure. 2. Research constellation model.

\section{B. Data Gathering Technique}

Data gathering in this research used instrument of questioner. Instrument development process was started by determining respondent and then continued to instrument arrangement referring to indicators in each variable and then the instrument was tested. Purpose of instrument testing was to examine validity and reliability of instrument elements that was used in research. Validity examination was conducted to observe how far the instrument can measure thing to be measured and be seen on validity and reliability instrument.

P.T. Gaharu Galangan Internasional is a company running on repair service and ship docking. Established in 2011 by the name of PT Mannnashipyard as stated in the deed of establishment no. 18 dated 9 February 2011.
It started from shipyard business (new shipbuilder) in Tanjung Uncang Batam in June 2011 to June 2013. The Company relocated shipyard business to Banjarmasin, South Kalimantan in June 2013; this was mainly to grab promising business opportunity in Banjarmasin. PT GGI is part of business of International Scale Company Group on Natural Resources, sea transport/maritime and shipping that has been active in Indonesia for more than 20 years.

\section{RESULTS AND DISCUSSION}

\section{A. Respondent Statistic}

Out of 50 respondents, there are 43 male respondents or $86 \%$ and 7 female respondents or $14 \%$. This shows that majority of respondents are male.

TABLE 2.

GENDER TYPE

\begin{tabular}{cccc}
\hline No. & Gender type & Frequency & $\%$ \\
\hline 1 & Male & 43 & $86 \%$ \\
2 & Female & 7 & $14 \%$ \\
\hline & Totals & 50 & $100 \%$ \\
\hline
\end{tabular}

Out of 50 respondents, it shows 18 persons or $36 \%$ have been working for 3 - 35 years, while respondents with service year $>5$ years are 32 persons or $64 \%$. This shows most service year is $>5$ years (Table 3 ). From these 50 respondents the age of $18-22$ years old constitute 23 persons or $46 \%$ and respondents with age of $22-27$ years old constitute 6 persons or $12 \%$, while respondents with age $>32$ years old make 21 persons or $42 \%$. This shows majority of age of respondents is $18-22$ years old (Table 4).

From these 50 respondents, it shows that 8 persons have high school/vocational school degree, 11 persons with D3 degree and 21 persons with S1/Bachelor's degree. It concludes that majority respondents have S1/Bachelor's degree (Table 5).

TABLE 3.

YEARS OF SERVICE

\begin{tabular}{rlcc}
\hline No. & Years of Service & Frequency & \% \\
\hline 1 & $3-6$ months & 0 & $0 \%$ \\
2 & $1-3$ years & 0 & $0 \%$ \\
3 & $3-5$ years & 18 & $36 \%$ \\
4. & $>5$ years & 32 & $64 \%$ \\
\hline & Totals & 50 & $100 \%$ \\
\hline
\end{tabular}

TABLE 4.

YEARS OF SERVICE

\begin{tabular}{|c|c|c|c|}
\hline No. & Age & Frequency & $\%$ \\
\hline 1 & $18-22$ years old & 23 & $46 \%$ \\
\hline 2 & $22-27$ years old & 6 & $12 \%$ \\
\hline 3 & $27-32$ years old & 0 & $0 \%$ \\
\hline \multirow[t]{2}{*}{4} & $>32$ years old & 21 & $42 \%$ \\
\hline & Totals & 50 & $100 \%$ \\
\hline
\end{tabular}


TABLE 5.

YEARS OF SERVICE

\begin{tabular}{clcc}
\hline No. & \multicolumn{1}{c}{ Last Education } & Frequency & $\%$ \\
\hline 1 & SD (elementary school) & 0 & $0 \%$ \\
2 & SMP (junior high school) & 0 & $0 \%$ \\
3 & SMA/SMK (senior high & 18 & $36 \%$ \\
& school) & 11 & $22 \%$ \\
4 & D3 (diploma 3) & 21 & $42 \%$ \\
\hline & Sarjana/Bachelor's Degree & 50 & $100 \%$ \\
\hline
\end{tabular}

\section{B. Data Analysis}

1) Structural 1:

Output and Interpretation of SPSS:

TABLE 6. MODEL SUMMARY

\begin{tabular}{|c|c|c|c|c|c|c|c|c|c|}
\hline \multirow[t]{2}{*}{ Model } & \multirow[t]{2}{*}{$\mathrm{R}$} & \multirow[t]{2}{*}{ R Square } & \multirow{2}{*}{$\begin{array}{l}\text { Adjusted } \\
\text { R Square }\end{array}$} & \multirow{2}{*}{$\begin{array}{l}\text { Std. Error } \\
\text { of the } \\
\text { Estimate }\end{array}$} & \multirow{2}{*}{$\begin{array}{l}\text { R Square } \\
\text { Change }\end{array}$} & \multicolumn{4}{|c|}{ Change Statistics } \\
\hline & & & & & & F Change & df1 & $\mathrm{df} 2$ & $\begin{array}{c}\text { Sig. F } \\
\text { Change }\end{array}$ \\
\hline 1 & $.068^{\mathrm{a}}$ & .005 & -.016 & 2.03002 & .005 & .221 & 1 & 48 & .640 \\
\hline 2 & $.000^{\mathrm{b}}$ & .000 & .000 & 2.01383 & -.005 & .221 & 1 & 48 & 640 \\
\hline
\end{tabular}

b. Predictor: (constant)

\begin{tabular}{|c|c|c|c|c|c|c|c|}
\hline & & & $\begin{array}{l}\text { TAB } \\
\text { AN }\end{array}$ & & & & \\
\hline Model & & Sum of Squares & $\mathrm{df}$ & Mean Square & $\mathrm{F}$ & Sig. & \\
\hline \multirow[t]{3}{*}{1} & Regression & .913 & 1 & .913 & .221 & $.640^{\mathrm{b}}$ & \\
\hline & Residual & 197.807 & 48 & 4.121 & & & \\
\hline & Total & 198.720 & 49 & & & & \\
\hline \multirow[t]{3}{*}{2} & Regression & .000 & 0 & .000 & & & c \\
\hline & Residual & 198.720 & 49 & 4.056 & & & \\
\hline & Total & 198.720 & 49 & & & & \\
\hline
\end{tabular}

TABLE 8.

COEFFICIENTS $^{\text {a }}$

\begin{tabular}{|c|c|c|c|c|c|c|}
\hline Model & & Unstandarized B & $\begin{array}{l}\text { Coefficients } \\
\text { Std. Error }\end{array}$ & $\begin{array}{l}\text { Standarized } \\
\text { Coefficients } \\
\text { Beta }\end{array}$ & $\mathrm{t}$ & Sig. \\
\hline 1 & $\begin{array}{l}\text { (Constant) } \\
\text { X1 }\end{array}$ & $\begin{array}{l}31.252 \\
.069\end{array}$ & $\begin{array}{l}5.507 \\
.146 \\
\end{array}$ & .068 & $\begin{array}{l}5.674 \\
.471 \\
\end{array}$ & $\begin{array}{l}.000 \\
.640\end{array}$ \\
\hline 2 & (Constant) & 33.840 & .285 & & 118.821 & .000 \\
\hline
\end{tabular}

Add that the coefficient of determination (R2) of 0.05 means that $5 \%$ variable variability (X2) can be described by (X1).

Table 6 shows determination coefficient (R2) is 0,05 , it means $5 \%$ of variable (X2) variability can be explained by (X1). Based on table 7 , result of variance analysis (ANOVA) is $\mathrm{F} 0=0.221 ; \mathrm{db} 1=1 ; \mathrm{db} 2=48$. p-value $0.640>0,05$ or Ho is accepted or variable X1 does not affect variable $\mathrm{X} 2$.

Based on table 8, path coefficient is obtained in Beta column (standardized Coefficient), that is path coefficient of $X 2$ to $X 1(\rho 21)=0,068$.
Tested Hypothesis is

$$
\begin{aligned}
& \mathrm{Ho}=\rho 21<0 \\
& \mathrm{H} 1=\rho 21>0
\end{aligned}
$$

Coefficients table shows value to $=0.471$ and $\mathrm{t}$ table $=$ 1,678 (at $\alpha=0,05$ ). Because $t$ calculation $=0,471<\mathrm{t}$ table $=1,678 \mathrm{so} \mathrm{H0}$ is accepted meaning path coefficient is nonsignificant. In that case $\mathrm{X} 1$ is not positively and directly affecting X2. Based on p-value $=0,640 / 2=0,32>0.05$ so Ho is accepted.

2) Structural 2:

TABLE 9 .

\begin{tabular}{|c|c|c|c|c|c|c|c|c|c|}
\hline \multirow[t]{2}{*}{ Model } & \multirow[t]{2}{*}{$\mathrm{R}$} & \multirow[t]{2}{*}{ R Square } & \multirow{2}{*}{$\begin{array}{l}\text { Adjusted } \\
\text { R Square }\end{array}$} & \multirow{2}{*}{$\begin{array}{l}\text { Std. Error } \\
\text { of the } \\
\text { Estimate }\end{array}$} & \multirow{2}{*}{$\begin{array}{l}\text { R Square } \\
\text { Change }\end{array}$} & \multicolumn{4}{|c|}{ Change Statistics } \\
\hline & & & & & & F Change & df1 & $\mathrm{df} 2$ & $\begin{array}{c}\text { Sig. F } \\
\text { Change }\end{array}$ \\
\hline 1 & $.616^{\mathrm{a}}$ & .379 & .352 & 2.42374 & .379 & 14.333 & 2 & 47 & .000 \\
\hline
\end{tabular}

MODEL SUMMARY

Coefficient of determination (R2) of 0379 means that $37.9 \%$ of X3 variables can be described by variables X2 and $\mathrm{X} 1$. 
International Journal of Marine Engineering Innovation and Research, Vol. 5(2), Jun. 2020. 81-91 (pISSN: 2541-5972, eISSN: 2548-1479)

TABLE 10

ANOVA $^{\mathrm{a}}$

\begin{tabular}{llrrrrr}
\hline Model & & Sum of Squares & df & Mean Square & F & Sig. \\
\hline 1 & Regression & 168.389 & 2 & 84.199 & 14.333 & $.000^{\mathrm{b}}$ \\
& Residual & 276.102 & 47 & 5.875 & & \\
& Total & 444.500 & 49 & & & \\
\hline
\end{tabular}

a. Dependent Variable: X3

b. Predictors: (Constant), X2, X1

TABLE 11.

COEFFICIENTS

\begin{tabular}{|c|c|c|c|c|c|c|}
\hline Model & & Unstandarized B & $\begin{array}{l}\text { Coefficients } \\
\text { Std. Error }\end{array}$ & $\begin{array}{l}\text { Standarized } \\
\text { Coefficients } \\
\text { Beta }\end{array}$ & $\mathrm{t}$ & Sig. \\
\hline \multirow[t]{3}{*}{1} & (Constant) & -4.112 & 8.500 & & -.484 & .631 \\
\hline & $\mathrm{X} 1$ & .713 & .175 & .470 & 4.081 & .000 \\
\hline & $\mathrm{X} 2$ & .548 & .172 & .367 & 3.181 & .003 \\
\hline
\end{tabular}

a. Dependent Variable: X3

From table 9, determination coefficient (R2) is 0,05 meaning $5 \%$ of variable $(\mathrm{X} 2)$ variability can be explained by (X1). Based on table 10, result of analysis of variance (ANOVA) is F calculation $=14.333 ; \mathrm{db} 1=1 ; \mathrm{db} 2=48$. p-value $0.00<0,05$ or Ho is rejected or variable X1 and X2 affect variable X3. Based upon SPSS table result above, path coefficient is obtained in Beta column (standardized Coefficient), that is path coefficient X2 to $\mathrm{X} 1(\rho 21)=0,068$.

Tested Hypothesis:

3) Structural 3

$$
\begin{aligned}
& \mathrm{Ho}=\rho 31<0 \\
& \mathrm{H} 1=\rho 31>0 \\
& \text { and } \\
& \mathrm{Ho}=\rho 32<0 \\
& \mathrm{H} 1=\rho 32>0
\end{aligned}
$$

$\rho 31=0.47 ; \mathrm{t}$ calculation $=4.081, \mathrm{p}$-value $=0.00 / 2=0,00$ $<0,005$ or Ho is rejected, it means there influence of X2 to $\mathrm{X} 3$ and $\rho 32=0,67 ; \mathrm{t}$ calculation $=3.181$, $\mathrm{p}$ value

\begin{tabular}{|c|c|c|c|c|c|c|c|c|c|}
\hline \multirow[t]{2}{*}{ Model } & \multirow[t]{2}{*}{$\mathrm{R}$} & \multirow[t]{2}{*}{ R Square } & \multirow{2}{*}{$\begin{array}{l}\text { Adjusted } \\
\text { R Square }\end{array}$} & \multirow{2}{*}{$\begin{array}{l}\text { Std. Error } \\
\text { of the } \\
\text { Estimate }\end{array}$} & \multirow{2}{*}{$\begin{array}{l}\text { R Square } \\
\text { Change }\end{array}$} & \multicolumn{4}{|c|}{ Change Statistics } \\
\hline & & & & & & F Change & df1 & df2 & $\begin{array}{c}\text { Sig. F } \\
\text { Change }\end{array}$ \\
\hline 1 & $.807^{\mathrm{a}}$ & .651 & .628 & 1.68944 & .651 & 28.553 & 3 & 46 & .000 \\
\hline
\end{tabular}
$0,03 / 2=0.015<0.05$ or Ho is rejected meaning $\mathrm{X} 2$ affects X3 (Table 11).

TABLE 12.

MODEL SUMMARY

TABLE 13.

\begin{tabular}{llcrrrr}
\multicolumn{7}{c}{ ANOVA $^{\mathrm{a}}$} \\
Model & & Sum of Squares & \multicolumn{1}{c}{ df } & Mean Square & F & Sig. \\
\hline 1 & Regression & 244.486 & 3 & 81.495 & 28.553 & $.000^{\text {b }}$ \\
& Residual & 131.294 & 46 & 2.854 & & \\
& Total & 375.780 & 49 & & & \\
& & & & & & \\
& & &
\end{tabular}

TABLE 14 COEFFICIENTS $^{\mathrm{a}}$

\begin{tabular}{lllllll}
\hline & & Unstandarized B & $\begin{array}{l}\text { Coefficients Std. } \\
\text { Error }\end{array}$ & $\begin{array}{l}\text { Standarized } \\
\text { Coefficients Beta }\end{array}$ & t & Sig. \\
\hline 1 & (Constant) & -.629 & 5.939 & & -.106 & .916 \\
& X1 & -.135 & .142 & -.097 & -.955 & .345 \\
& X2 & -.093 & .132 & -.068 & -.704 & .485 \\
& X3 & .805 & .102 & -.876 & 7.921 & .000 \\
\hline
\end{tabular}

Table 12, determination coefficient $\left(\mathrm{R}^{2}\right)$ is 0.651 meaning that $65,1 \%$ of variable $Y$ can be explained by variable X3, $\mathrm{X} 2$ and X1. From table 13, result of variance analysis (ANOVA) is F calculation $=28.553 ; \mathrm{db} 3=1 ; \mathrm{db} 2=46$. p-value $0.00<0,05$ or Ho is rejected or variables X1, X2, $\mathrm{X} 3$ affect variable $\mathrm{Y}$, furthermore:

$$
\begin{aligned}
& \mathrm{Ho}=\rho \mathrm{y} 1<0 \\
& \mathrm{H} 1=\rho \mathrm{1} 1>0 \\
& \text { and }
\end{aligned}
$$




$$
\begin{aligned}
& \mathrm{Ho}=\rho \mathrm{y} 2<0 \\
& \mathrm{H} 1=\rho \mathrm{y} 2>0 \\
& \mathrm{Ho}=\rho \mathrm{y} 3<0 \\
& \mathrm{H} 1=\rho \mathrm{y} 3>0
\end{aligned}
$$

From table 14 coefficient is obtained as follows: py $1=-0,97 ; \mathrm{t}$ calculation $=-0,955$, $\mathrm{p}$-value $=0,345 / 2=$ $0,1723>0.05$, Ho is accepted meaning $\mathrm{X} 1$ does not affect directly and positively $\mathrm{Y}$. py $2=-0,68 ; \mathrm{t}$ calculation $=-0,68, \mathrm{p}$ value $=0,485 / 2=$ $0,2425>0.05$, Ho is accepted meaning X2 does not affect directly and positively $\mathrm{Y}$.

py $3=0,876 ;$ calculation $=7.921, \mathrm{p}$ value $=0,00 / 2=0,00$ $<0.05$, Ho is rejected meaning X3 affects directly and positively Y.

Values obtained from path analysis reveal influence (beta coefficient). If the value is positive, it means one variable is connected positively with the other, and one improving variable needs another improving variable. Also, if the value is negative, it means one improving

\begin{tabular}{|c|c|c|c|c|}
\hline No & Hypothesis & $\begin{array}{l}\text { Statistical } \\
\text { Testing }\end{array}$ & Result & Conclusion \\
\hline 1 & $\begin{array}{l}\text { Loyalty of employee (X1) affects directly } \\
\text { performance of employee (Y) }\end{array}$ & $\begin{array}{l}\mathrm{Ho}=\rho \mathrm{y} 1<0 \\
\mathrm{H} 1=\rho \mathrm{y} 1>0\end{array}$ & Ho is accepted & not affected directly and positively \\
\hline 2 & $\begin{array}{l}\text { Followership (X2) affects directly performance } \\
\text { of employee (Y) }\end{array}$ & $\begin{array}{l}\mathrm{Ho}=\rho \mathrm{y} 2<0 \\
\mathrm{H} 1=\rho \mathrm{y} 2>0\end{array}$ & Ho is accepted & not affected directly and positively \\
\hline 3 & $\begin{array}{l}\text { Leadership style (X3) affects directly } \\
\text { performance of employee }(\mathrm{Y})\end{array}$ & $\begin{array}{l}\mathrm{Ho}=\rho \mathrm{y} 3<0 \\
\mathrm{H} 1=\rho \mathrm{y} 3>0\end{array}$ & Ho is rejected & affected directly and positively \\
\hline 4 & $\begin{array}{l}\text { Loyalty of employee (X1) affects directly } \\
\text { Followership (X2) }\end{array}$ & $\begin{array}{l}\mathrm{Ho}=\rho 21<0 \\
\mathrm{H} 1=\rho 21>0\end{array}$ & Ho is accepted & not affected directly and positively \\
\hline 5 & $\begin{array}{l}\text { Loyalty of employee (X1) affects directly } \\
\text { leadership style (X3) }\end{array}$ & $\begin{array}{l}\text { Ho }=\rho 31<0 \\
\mathrm{H} 1=\rho 31>0\end{array}$ & Ho is rejected & affected directly and positively \\
\hline 6 & $\begin{array}{l}\text { Followership (X1) affects directly leadership } \\
\text { style (X3) }\end{array}$ & $\begin{array}{l}\mathrm{Ho}=\rho 32<0 \\
\mathrm{H} 1=\rho 32>0\end{array}$ & Ho is rejected & affected directly and positively \\
\hline
\end{tabular}
variable will reduce the other connected variable.

TABLE 15.

RECAPITULATION OF HYPOTHESIS TESTING RESULT

Result of Constellation Model after Testing is as follows:

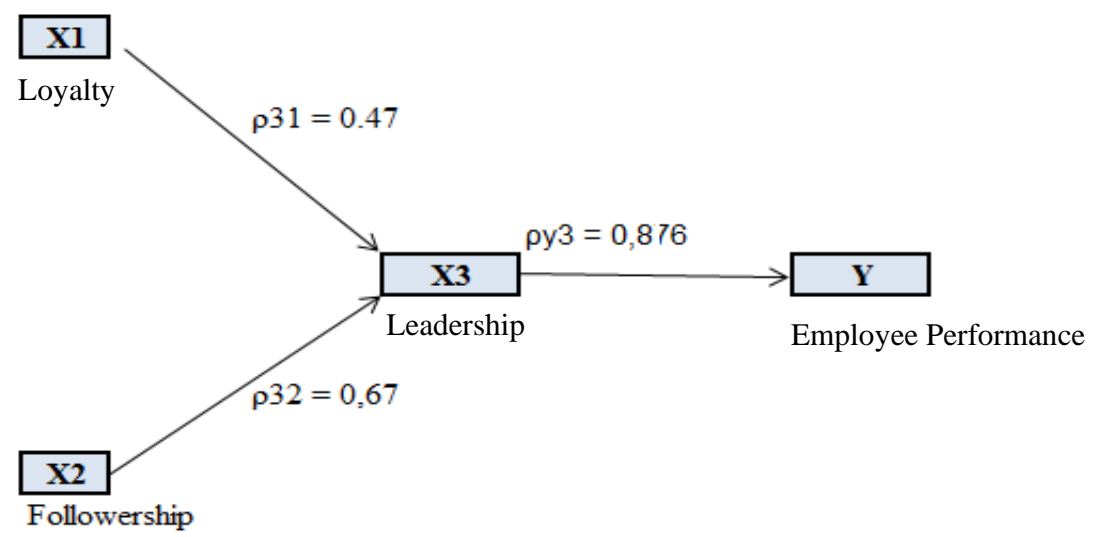

Figure. 3. Constellation model after testing.

Path analysis shows no direct influence of loyalty variable to employee performance and followership to employee performance, yet those two variables influence employee performance by way of leadership style variable as intervening variable.

\section{Influence of employee loyalty on employee performance}

Based on research result there is no direct influence of employee loyalty to employee performance even though by theory and supporting consensus that employee loyalty generates value to the organization. Several researches result are as follows: Research conducted by Olivia Guillon, Cécile Cezanne [16] shows ambiguity about concept theory and loyalty practice as value resource for organization or influence to employee performance or company. This study shows that relationship between loyalty and performance of employee varies in accordance with indicator type used [16]. Study conducted by Rhispal \& Manish [17] shows researcher make clear indicators 
between loyal and disloyal employees, they are indicators of: planning, decision making, Effective execution and Result Producing Capability. When average score of those indicators show score of $(20,4)$ for loyal and $(13,2)$ for disloyal, it means employee loyalty affects employee performance by certain indicator.

Based on study conducted by Ivana [18] on variables of employee loyalty, service quality, cost reduction and company performance that employee loyalty affects positively service quality, employee loyalty also affects reducing cost directly and positively. Result of path analysis shows that all variables have causal impact on performance. Based on this research, it can be concluded that there variable influence defined on company performance and investigated relationship will contribute to increase performance of service company. Other several researches show how important the behavior of employees. ,including employee loyalty, and its impact on operational performance has been mostly ignored, and loyal employee is able more and has more impact to higher service quality, which has indirect impact to performance of company [19]. If employees are committed to organizing and performing on higher level, this gives positive and indirect impact on performance of organization [20]. There is significant linear correlation between employee loyalty, involvement and performance. Positive correlation of human relationship, leadership style, creativity and its effect on loyalty of employees. In order to meet performance target, loyalty and involvement of employees have to be considered [21].

\section{Influence of followership on performance of employee}

This research shows there is no direct impact follower type (followership) to performance of employee. It is in line with research result by [22] in Ghana, out of follower type there are only star followers type and type of opportunistic (pragmatic followers) that are dominant. There is no difference in performance of employee with star follower style and opportunistic styles, pragmatic follower style. But this research still advices that leader encourages employees to be star/role model and also think steps to alter non-star followers to be star-followers. Research of Amanolah [23] shows there is significant difference between various followers in their working motivation and work performance and follow-up test. Scheffe reveals that star followers and conformity followers have higher performance than other followers. In such a manner, it is concluded that leaders and managers in organization must consider followership role critical in achieving productivity in the organization.

Research conducted by 102 private lecturers in Botswana is to identify if there is significant relationship between follower style in relation to work performance. Data shows that (a) the most common followers style in lecturers is Pragmatic followers style, (b) there is no relationship between follower style and work performance, (c) there is strong relationship between passive follower style and work performance; this shows low performance and some lecturers pragmatic character. Character is needed even though lecturer work performance that shows star followers style is low. Not only follower character as role model is desired but it is responsible to the increasing organization performance and goal achievement [24].

\section{E. Influence of Leadership Style on Employees Performance}

Based on this research, only variable of leadership style affects directly to employee performance and this variable is also intervening variable from loyalty variable and followership variable. Many theories and research results say that leadership style affects employee performance, Irfanullah \& Nawaz [25] states that Leadership style is the way to give direction, implement strategy and motivate individual toward wanted goal achievement. Leadership style is replicated in attitude and behavior, but this is result of complicated interaction between way of thinking and sensing. Researcher focuses on various approaches/leadership styles based on different assumption and theory. They elaborate leadership effectivity in reorganization including authority establishment, encourage responsibility, simplify and manage employees' issues in existing situational context. The result is, among others, two leadership styles are more prominent. They are leadership styles of transformational and transactional. These two styles have been analyzed in various socioeconomic and academic sectors with each distinctive advantage. Recently both styles work in different situation depending on the character and contexts.

Leadership role on increasing employee performance has been studied long time ago by scholars in management field. The discussion is developed into argument about practice of the most affecting leadership style in organization. Transformational leadership has been identified as one factor to contribute to employees' performance.

Influence of idealism, motivation, inspiration, intellectual stimulus and individual consideration is transformational leadership dimension that has been proven to increase employee performance [26]. Leadership behavior of Chief Executive Officer (CEO) and company performance to bring critical behavior to increase performance result. Leadership behavior is measured based on transactional and transformational leadership behaviors, and performance is measured based on sales growth, profit, market share and employment growth and owner satisfaction. Result shows that leadership style has statistical significance with performance. In particular, transformational behavior from individual consideration and ideal influence significantly is linked to sales, profit, growing employment and owner satisfaction, meanwhile inspirational motivation and intellectual stimulation is related to growing work, profit and owner satisfaction. Moreover, management transactional behavior significantly is related to growing sales, profit and growing work. Yet this type of leadership has weak relationship or not at all with market share significantly [27].

\section{F. Influence of Loyalty on Leadership Style}

Based on research result, employee loyalty affects leadership style, meaning a leader can easily manage high loyal employees and absolutely leadership style will be 
different according to employee behavior. This is in accordance with study by Rita [28] on employees of RS Islam Hidayatullah, Yogjakarta, Based on regression testing result, there is positive and significant influence of leadership style on employee performance, also there is positive and significant influence of employee loyalty on employee performance of RS Islam Hidayatullah Yogyakarta. Based on correlation testing, independent variable (leadership style and employee loyalty affects positively and significantly employee performance. Other research is to identify transactional leadership style and transformational leadership style affects employee loyalty in Hotel X Bali or not. The result shows that transactional leadership style affects positively and significantly, also transformational leadership style affects positively and significantly employee loyalty of Hotel X Bali [29].

The difference is research by Ali et al. [20], loyalty and work satisfaction gain significant interest in work place study. This is based on general acknowledgement that these variables can be determining factors on performance and effectivity of organization. Research study shows that traditional leadership style in Iran automotive industry is used dominantly by manager and the result is employee satisfaction level is low. Traditional leadership style has negative relationship with employee satisfaction. There is also negative connection between leadership style and employee loyalty [13].

\section{G. Influence of Followership on Leadership style}

The result shows there is direct influence of followership variable on leadership style. Several followership-leadership research results are as follows: Leader has been classified to have charismatic, ideological and pragmatic (CIP) leadership styles; each has different patterns in cognition and interaction. Notwithstanding each CIP style has been shown to facilitate certain aspects from creative process of follower. The question is still about the impact of leadership style on creative performance of follower entirely. One factor possibly affects this relationship is leader distance consisting of physical distance, sensed social distance and task interaction sensed by leaders and followers. By using CIP leadership model, the researcher explores leader distance and appropriate mental model leader-follower on follower creative performance. The result shows leadership style doesn't directly affect follower creativity; it interacts with leader distance to create creative result. [30].

The following research states that the followers are different in defining and treating follower role which can have various effects in relation to how the leaders experience role and responsibility of their own. This research shows that follower voice and delegation to upper level mediate relationship that links to coproduction and follower passive role orientation with output valued by the leader. This shows that follower role orientation and behavior influence differently the leader's perception concerning their follower support, contribution on goal achievement and leader motivation [31].

\section{CONCLUSION}

Based on data analysis and conducted discussion, it can be concluded as follows :

1. Hypothesis \#1: it states that there is expectedly direct positive influence of Loyalty $\left(\mathrm{X}_{1}\right)$ on Team Performance (Y), it is not accepted.

2. Hypothesis \#2: it states that there is expectedly direct positive influence of Followership $\left(\mathrm{X}_{2}\right)$ on Team Performance (Y), it is not accepted.

3. Hypothesis \#3: it states that there is expectedly direct positive influence of Leadership $\left(\mathrm{X}_{3}\right)$ on Team Performance (Y), it is accepted.

4. Hypothesis \#4: it states that there is expectedly direct positive influence of Loyalty $\left(\mathrm{X}_{1}\right)$ on Leadership $\left(\mathrm{X}_{3}\right)$, it is accepted.

5. Hypothesis \#5: it states that there is expectedly direct positive influence of Followership $\left(\mathrm{X}_{2}\right)$ on Leadership $\left(\mathrm{X}_{3}\right)$, it is accepted.

6. Hypothesis \#6: it states that there is expectedly direct positive influence of Loyalty (X1) on Followership (X2), it is not accepted.

Proposed recommendations based on analysis result, discussion and conclusion for PT Gaharu Galangan Internasional are as follows:

1. Leadership is always deemed requirement for organization success. Given the fast pace of increasing and developing communication technology along with the rising of international business by way of globalization, leadership issue has been instrumental factor, that's why leadership competencies have to be increased in relation to enhancing loyalty and followership of employees on their performance.

2. Employees need to enhance their determination and willingness to comply, conduct and practice responsibly and consciously what they have to in work accomplishment as part of individual factor and also participate in achieving common goal. Because even though employees have already had appropriate abilities and skills, but without high loyalty spirit to get involved in work accomplishment, the performance result will not be optimal.

\section{REFERENCES}

[1] Amstrong, M. and Baron, A, (2011). Managing Performance Management in Action, UK:CIPD Publishing.

[2] Kelley, R. (1992). The Power of Fellowership, New York, NY Doubleday.

[3] Northouse, P. G. (2016). Leadership: theory and practice. Leadership: theory and practice (6th editio). Thousand Oaks, CA: Sage Publisher.

[4] Samuel C. Certo, S. T. C. (2011). Modern Management Concept and Skills (Twelfth Ed). London: Pearson Education, Inc.

[5] Maxwell, J. C. (2012). 5 Levels of Leadership. (M. T, Ed.) Surabaya: PT Menuju Insan Cemerlang).

[6] Yukl, G. (2015). Leadership in Organizations (7th Editio). New Jersey: Pearson Education, Inc.

[7] Bennis, W. (2008). The Art of Followership: How Great Followers Create Great Leaders and Organisations. San Francisco, CA, USA: Jossey=Bass.

[8] Stephen P. Robbins;Mary A. Coulter. (2018). Management (14th ed.). Pearson Education, Inc.

[9] Siswanto (2005), Pengantar Manajemen, Jakarta, P.T. Bumi Aksara.

[10] Saydam, Gouzalli(2000), Manajemen Sumber Daya Manusia (human Resources), Suatu Pendekatan Mikro, Djanbatan, Jakarta. 
[11] Yusuf, Pawit, M. (2010), Komunikasi Instruksional Teori dan Praktek, Jakarta, P.T. Bumi Aksara.

[12] Burge, L. M. (2009). Correlation of Followership and Leadership styles of Medical Sience Liaisons Within the Pharmaxwutical and Biopharmaceutical Industry. Capela University.

[13] Gashti;, M. A. H. V. T. F. (2014). The Relationship between Leadership styles, employee satisfaction and loyalty. International Journal of Human Resource \& Industrial Research (IJHRIR), 1(2), 36-45.

[14] AB. Susanto(2009). Reputation Driven Corporate Social Responsibility, Jakarta, Airlangga.

[15] Noe. (2002). Employee Training and Development. New York: MC.Graw-Hill.

[16] Olivia Guillon, C. C. (2014). Employee loyalty and organizational performance: a critical survey. Journal of Organizational Change Management, 27(5), 839-850.

[17] Rishipal \& Manish. (2013). Performance Management \& Employee Loyalty. Global Journal of Management and Business Research Adminitration \& Management, 13(3).

[18] Ivana Tomic, Zdravko Tesic, B. K. \& M. T. (2018). An empirical study of employee loyalty, service quality, cost reduction and company performance. Journal Economic Research-Ekonomska Istraživanja, 1(1), 827-846.

[19] Yee, R. W. Y., Yeung, A. C. L., \& Cheng, T. C. E. (2010). An empirical study of employee loyalty, service quality and frm performance in the service industry. International Journal of Production Economics, 124, 109-120., 124, 109-120.

[20] Ali, I., Rehman, K. U., Ali, S. I., Yousaf, J., \& Zia, M. (2010). Corporate social responsibility influences, employee commitment and organizational performance. African Journal of Business Management, 4(13), 2796-2801.

[21] John, P. A. A. (2013). A Study on the Concept of Employee Loyalty and Enga gement on the Performance of Sales Executives of Commercia 1 Banks in GHANA. International Journal of Business Research and Mana Gement (IJBRM), (4)(2), 51-62.

[22] Sampson Ntiamoah. (2018). Influence of Followership Behaviors on Employee Job Performance in Some Selected Public Universities in Ghana. International Journal of Scientific and Research Publications, 8(2). [23] Amanollah, M., \& Nejad;Abdolzahra Naami. (2015).
Followership Styles: The Difference of Employees in Their Job Motivation and Job Performance. International Journal of Psychology, 9(1).

[24] Christianah O. Oyetunji. (2013). The Relationship between Followershi p Style and Job Performance in Botswana Private Universities. International Education Studi Es, 6(2), 179-187.

[25] Irfanullah Khan; Allah Nawaz. (2016). The leadership styles and the employees performances: A Review. Gomal University Journal of Research [GUJR], 32(2), 144-150.

[26] Husna, N. M., \& Hussain. (2017). Leadership Style and Employee Performance. In Proceeding of the 4 th International Conference on Management and Muamalah (pp. 655-660). ISBN: 978 - 967 -2122 - $15-9$.

[27] Niyi, A. (2016). Chief Executive Officer Leadership Role and Small and Medium Enterprises Performance in Southwest Nigeria. International Jornal of Advance in Management and Economics, 5(5), 40-49.

[28] Rita Ivana Ariyani. (2016). Pengaruh Gaya Kepemimpinan dan Loyalitas Karyawan Terhadap Kinerja Karyawan di Rumah Sakit Islam Hidayatullah Yogyakarta. Jurnal Medicoeticolegal Dan Manajemen Rumah Sakit, 5(2), 136-142.

[29] Sieny Carolina; Grace Angelica Halim. (2017). Analisa Pengaruh Gaya Kepemimpinan Terhadap Loyalitas Karyawan Hotel X di Bali. Jurnal Hospitality Dan Manajemen Jasa, 5(2), 328-341.

[30] Jennifer A Grifth; Carter Gibson; Kelsey Medeiros; Alexandra MacDougall; Jay Hardy. (2018). Are You Thinking What I'm Thinking?: The Influence of Leader Style, Distance, and LeaderFollower Mental Model Congruence on Creative Performance. Journal of Leadership \& Organizational Studies, 25(2), 153 170.

[31] Melissa K Carsten; Mary Uhl-Bien; Lei Huang. (2017). Leader perceptions and motivation as outcomes of followership role orientation and behavior. Leadership Quarterly - Sage.

[32] Robert E. Kelley. (1992). The Power of Followership. New York:Doubleday Business. FBI Law Enforcement Bulleti, 77(7) 